\title{
INFLUENCE OF LEADERSHIP AND DISCIPLINE ON PERSONNEL PERFORMANCE OF KODAM JAYA / JAYAKARTA
}

\author{
Zahroni $^{1}$, Dr. Rahimullah, SH, M.Si ${ }^{2}$, Dr. Ir. Sriyono Joko Sutopo, MS ${ }^{3}$ \\ Postgraduate Program Student, Master of Management Study Program, Satyagama University, Jakarta, Indonesia ${ }^{1}$, Chairman of \\ the Supervising Team ${ }^{2}$, Members of Supervising Team ${ }^{3}$ \\ DOI: $10.31364 / \mathrm{SCIRJ} / \mathrm{v} 8.11 .2020 . \mathrm{P} 0120740$ \\ http://dx.doi.org/10.31364/SCIRJ/v8.i1.2020.P0120740
}

\begin{abstract}
Personnel performance is one of the problems faced by almost all Organizations because it is related to the achievement desired by the Organization. The problem arises, among others, because the leader is less in supervising subordinates at work. Leaders do not voice enough to meet the needs of personnel. Personnel who are not on time every day at the Organization. There are personnel who are not disciplined in doing their work. Based on these considerations, this study aims to determine the Effect of Leadership and Discipline on the Performance of Kodam Jaya / Jayakarta Personnel.

Research on the Influence of Leadership and Discipline on the Performance of Kodam Jaya / Jayakarta Personnel uses a quantitative method with an explanatory research type, with a population of 200 people and a sample / respondent of research totaling 67 people determined by the Slovin formula. Data collection techniques in the study of the Effect of Leadership and Discipline on the Performance of Kodam Jaya / Jayakarta Personnel is a list of statements using the Liekert scale.

From the research it was concluded that there was an Influence of Leadership on the Performance of Kodam Jaya / Jayakarta Personnel at $60.7 \%$ and the influence of discipline on the performance of Kodam Jaya / Jayakarta personnel at 58.7\%, while jointly on the performance of Kodam Jaya / Jayakarta personnel could be optimized through efforts to strengthen leadership and work discipline of personnel by $74.5 \%$ which means the performance of Kodam Jaya / Jayakarta personnel must be considered so that the performance of Kodam Jaya / Jayakarta personnel in the future is better.
\end{abstract}

Keywords: Leadership, Discipline, Personnel Performance.

\section{BACKGROUND}

Based on the results of the interview, it can be seen that indicators of low performance of personnel are shown, such as personnel not completing tasks assigned in a timely manner, personnel working not in accordance with specified working hours, personnel are rarely absent if they are not really in a state of urgency, personnel do not work same with coworkers, personnel are not happy to help colleagues who have difficulty working.

One of the efforts of agencies in maintaining personnel performance is the presence of good leadership. Leadership (leadership) can be said as a way of a leader (leader) in directing, encouraging and regulating all the elements in the group or organization to achieve the desired organizational goals so as to produce maximum quality work of personnel. Increasing the quality of work of personnel means the achievement of one's work or personnel in realizing the goals of the organization.

The ability and skills of a leader are important factors in motivating their personnel to work better. In this case the influence a leader really determines the direction of the goals of the organization, because to realize the goals of the organization needs to apply the role in leading work that is consistent with the work situation at hand. In addition, a leader in carrying out their duties must strive to create and maintain good relationships with subordinates so that they can work productively. Thus, indirectly the motivation of personnel is increasing.

The leader functions to guide, guide, guide, develop work motivation, drive the organization, establish good communication, conduct regular supervision, and direct the subordinates to the targets to be addressed. Associated with it is the duty of every leader so that his subordinates are motivated to work even better. The role of leadership is also a way owned by someone to influence a group of people or subordinates to work together and empower efforts with enthusiasm and confidence to achieve the goals set. The success of an organization, both as a whole and as a group in a particular organization, is very dependent on the effectiveness of leadership to arouse the motivation or enthusiasm of the work of personnel towards their duties and responsibilities.

Based on the description above, this study takes the title "The Effect of Leadership and Discipline on the Performance of Personnel Kodam Jaya / Jayakarta".

The objectives in this study are:

1. To analyze the effect of leadership on the performance of Kodam Jaya / Jayakarta personnel.

2. To analyze the effect of discipline on the performance of Kodam Jaya / Jayakarta personnel. 
3. To analyze the influence of leadership and discipline together on the performance of Kodam Jaya / Jayakarta personnel.

While the uses in this study are as follows:

1. Theoretical use

This research is useful to add knowledge and insight, as well as to be able to apply theories and concepts relating to human resources obtained from lectures, especially regarding personnel performance.

2. Practical use

a. The results of this study are expected to be a useful input and consideration for Kodam Jaya / Jayakarta in improving personnel performance.

b. In addition to and expanding knowledge for researchers in the field of management, specifically regarding leadership and disciplines related to performance.

\section{LITERATURE REVIEW}

\section{Leadership in Improving Personnel Performance}

The leadership factor plays an important role in the overall effort to improve performance, both at the individual or organizational level. It was said so because the performance did not highlight the angle of implementing personnel who are generally technical but from the group and managerial as well. Stephen Robbins P (2003:54) states that performance is positively influenced when the leader compensates for things lacking in personnel in work situations. This means that leadership to influence personnel through the communication process to achieve organizational goals is expected to lead to positive changes in the form of dynamic forces that can coordinate the organization in order to achieve goals if set according to the corridor that has been established by both parties in accordance with their positions.

\section{Discipline in Improving Personnel Performance}

Work discipline can have an impact on the personal lives of personnel who influence the organization. For this reason, the organization needs to oversee every action and behavior carried out by personnel while working. If there is an act of fraud that is not in accordance with the rules or something that is annulled from the facts, the organization should determine the punishment for its personnel. Even superiors should know and implement the rules in the organization.

According to Masyjui in Sudarmanto (2009) a personnel who has a high work discipline can be seen from: timeliness, using office equipment properly, high responsibility, and adherence to office rules. Punctuality is shown from the actions of the personnel who arrive at the office on time, in an orderly and orderly manner, so that it can be said of good work discipline. Using office equipment properly is shown from the attitude of caution in using office equipment, thus showing that someone has good work discipline, so that office equipment can avoid damage. High responsibility is shown from the awareness of personnel who always complete the tasks assigned to them in accordance with procedures and responsibility for the work, so that it can also be said to have good work discipline. Compliance with office rules is shown by personnel wearing office uniforms, using ID cards, making permits when not entering the office, is also a reflection of high discipline. If the indicators of work discipline exist in personnel, it can improve personnel performance. Discipline of personnel work can be realized if personnel are aware or have a willingness to carry out the duties and regulations of the company, comply with applicable norms about what rules may and what should not be done by personnel during the organization and as a reference in acting, and responsible ability to carry out tasks and regulations in the organization (Hasibuan, 2013). Someone will carry out their duties well and full of responsibility if these personnel have high work discipline. Work discipline is one of the requirements to be able to help personnel work productively which will help improve personnel performance.

\section{Leadership and Discipline Together in Improving Personnel Performance}

Optimal personnel performance is expected by every organization. According to Prawirosentono (2001) performance is the result of work that can be achieved by a person or group of people in an organization, in accordance with their respective authorities and responsibilities in an effort to achieve organizational goals legally, not violating the law and in accordance with morals and ethics. Achievement of personnel performance is still not optimal because there are still programs / activities whose realization has not been achieved in accordance with the targets set.

Whether or not the performance of personnel can be influenced by leadership and work discipline factors. The success of an organization is determined by the leadership that is developed in the organization given to subordinates to achieve goals. Without good leadership, it will be difficult to achieve organizational goals, even to adapt to changes that are happening inside and outside the organization. A harmonious relationship between personnel and leaders is a problem that needs attention when connected with job satisfaction. While work discipline is very necessary in order to carry out programs it works to achieve the set goals. If personnel have high work discipline, it will help improve personnel performance.

\section{RESEARCH METHODS}

To explore the formulation in this research, a quantitative approach is used, which is a type of research that basically uses a deductive approach. This approach departs from a theoretical framework, the ideas of experts, and understanding of researchers 
based on their experience, then developed into problems and solutions proposed to obtain justification (verification) or assessment in the form of empirical data support in the field with the technique of collecting questionnaires, interviews, and observation.

The research location is a place or area where the research will be conducted. The research site that will be carried out by the author is at the Jaya Military Command / Jakarta from the implementing unit, Ajendam Jaya, as a work unit of 200 people in 2019.

\section{RESEARCH RESULTS AND DISCUSSION}

Test requirements analysis in the study of the Influence of Leadership and Discipline on the Performance of Kodam Jaya / Jayakarta Personnel is a data instrument test in the form of a validity test and a reliability test. For each test described as follows:

\section{A. Test Validity}

Validity test is done to find out the level of validity and the instrument (questionnaire) used in data collection. The validity requirements of the instrument (questionnaire) are $r$ count value> $r$ table.

a. Leadership Variable $\left(\mathbf{X}^{1}\right)$

From the results of transportation can be seen that the r-count value of leadership variables obtained was apparently greater than r-table $(0.235)$ or r-count> r-table and all 15 research instrument data items are said to be valid. With the dominant indicators are clear structure, broad insight, monitoring, communication, and completing infrastructure.

b. Variable Knowledge About Work Discipline $\left(\mathbf{X}^{2}\right)$

From the calculation results it can be seen that the r-count value of the work discipline variable obtained turns out to be greater than r-table $(0.235)$ or r-count> r-table and all 15 research instrument data items are said to be valid, with the dominant indicator being present be on time, have loyalty, orderly, do not damage office equipment, and must comply with the provisions.

c. Personnel Performance Variable (Y)

From the results of calculations it can be seen that the r-count value of the performance variable obtained is greater than the r-table $(0.235)$ or r-count> r-table and all 15 research instrument data items are said to be valid, with the dominant indicator being organizational management, skills, organizational programs, receiving input, and expenses.

\section{B. Reliability Test}

Reliability tests are carried out to determine whether the instrument is used more than once, will produce consistent data. In this study, the reliability test was carried out using the Alpha Cronbach technique. The instrument is declared reliable if the Cronbach Alpha value> 0.6.

Tabel 1.

Hasil Uji Reliabilitas

\begin{tabular}{|c|l|c|c|}
\hline \multirow{2}{*}{ No } & \multicolumn{1}{|c|}{ Variabel } & $\begin{array}{c}\text { Alpha } \\
\text { Cronbach }\end{array}$ & \multirow{2}{*}{ Keterangan } \\
\cline { 2 - 3 } 1 & Kepemimpinan $\left(\mathrm{X}_{1}\right)$ & 0,958 & \multirow{2}{*}{ Reliabel } \\
\hline 2 & Disiplin Kerja $\left(\mathrm{X}_{2}\right)$ & 0,965 & \\
\hline 3 & Kinerja Personel $(\mathrm{Y})$ & 0,857 & \\
\hline
\end{tabular}

Source: SPSS 17 for windows

Based on the results of testing the reliability of the instrument shows that the instrument used is reliable which means the instrument can be trusted enough to be used as a data collection tool.

\section{Classical Assumption Test}

The classical assumptions tested consisted of three tests, including the normality test, the multicollinearity test, and the heteroscedasticity test.

\section{a. Normality test}

Normality test to find out whether the dependent variable, independent or both are normally distributed, close to normal or not. Detect a data with normal distribution or cannot be known through statistical analysis. To be able to see whether the multiple regression model has a normal distribution or not the Kolmogorov-Smirnov One-Sample test is used for unstandardized residual data at a significance level $(\alpha)$ of 0.05 . If the significance value is greater than 0.05 , this indicates that the data is normally distributed.

Tabel 2.

Nilai Probabilitas Uji One-Sample Kolmogorov-Smirnov 
One-Sample Kolmogorov-Smirnov Test

\begin{tabular}{|ll|r|}
\hline & & \multicolumn{1}{|c|}{$\begin{array}{c}\text { Unstandardiz } \\
\text { ed Residual }\end{array}$} \\
\hline N & & 67 \\
Nomal Parameters $\quad \mathrm{a}, \mathrm{b}$ & Mean & .0000000 \\
Most Extreme & Std. Deviation & .22310797 \\
Differences & Absolute & .100 \\
& Positive & .043 \\
Kolmogorov-Smimov Z & Negative & -.100 \\
Asymp. Sig. (2-tailed) & & .819 \\
\hline
\end{tabular}

a. Test distribution is Normal.

b. Calculated from data.

Based on the table above, it can be seen that the value of Kolmogorov-SmirnovZ is 0.819 with a probability value of 0.514. Because the estimated probability of results is greater than the real significance level determined $(0.514>0.05)$, it can be concluded that the unstandardized residual data has a normal distribution.

\section{b. Heteroscedasticity Test}

Heteroscedasticity test is performed to find out whether in a regression model there is an inequality of variance from the residuals of one observation to another. Estimation results using SPSS program application assistance are presented through the Glejs test where the independent variables are re-registered with absolute standardized residual data at a significance level $(\alpha)$ of 0.05 . If the significance value of each independent variable is greater than 0.05 , it shows that the data has fulfilled the homoscedasticity assumption.

Tabel 3.

Nilai Probabilitas Uji Heteroskedastisitas Glejser Coefficients $^{\mathrm{a}}$

\begin{tabular}{|c|c|c|c|c|c|}
\hline \multirow[t]{2}{*}{ Model } & \multicolumn{2}{|c|}{$\begin{array}{l}\text { Unstandardized } \\
\text { Coeffcients }\end{array}$} & $\begin{array}{l}\text { Standardized } \\
\text { coefficients }\end{array}$ & \multirow[t]{2}{*}{$\mathrm{t}$} & \multirow[t]{2}{*}{ Sig } \\
\hline & $\mathrm{B}$ & Std. error & Beta & & \\
\hline (Constant) & ,248 &, 083 & & 3,006 & ,004 \\
\hline Kepemimpinan $\left(\mathrm{X}_{1}\right)$ & ,013 & 032 & ,064 & ,412 & 682 \\
\hline Disiplin Kerja $\left(\mathrm{X}_{2}\right)$ &,- 041 & 031 &,- 205 & $-1,327$ & , 189 \\
\hline
\end{tabular}

a. Dependent Variable: Abs_Res1

Based on the table above, it can be seen that the magnitude of the probability value of each independent variable namely Leadership $(X 1)=0.682$ and Work Discipline $(X 2)=0.189$. Because the value of the probability of the estimation results of each independent variable is greater than the real significance level determined $(0.05)$, it can be concluded that the data has fulfilled the assumption of homoscedasticity.

c. Multicollinearity Test

The multicollinearity test aims to evaluate the presence or absence of strong correlations between independent variables, where there is a strong correlation between independent variables indicating that the use of independent variables in the regression model is inefficient. By using the SPSS program application, it is obtained the estimated results of the VIF value of each independent variable for multicollinearity test as follows:

Tabel 4.

Nilai VIF Uji Multikolinieritas Coefficients $^{\mathrm{a}}$

\begin{tabular}{|c|c|c|c|}
\hline & \multirow{2}{*}{ Model } & \multicolumn{2}{|c|}{ Collinearty Statistics } \\
\hline & & Tolerance & VIF \\
\hline & $\begin{array}{l}\text { Kepemimpinan }\left(\mathrm{X}_{1}\right) \\
\text { Disiplin Kerja }\left(\mathrm{X}_{2}\right)\end{array}$ & $\begin{array}{l}634 \\
, 634\end{array}$ & $\begin{array}{l}1,557 \\
1,557\end{array}$ \\
\hline
\end{tabular}

a. Dependent Variable: Kinerja Personel (Y) 
The estimated results of the VIF value presented through the table above shows that the VIF value of each independent variable is below the critical value of 10 , namely Leadership $(X 1)=1,557$ and Work Discipline $(X 2)=1,557$. Based on these results, it can be concluded that there is no multicollinearity between independent variables in the regression model.

\section{Hypothesis Testing}

Hypothesis testing conducted in this study is by two-sided or two-sided test techniques. Then based on the results of testing the three hypotheses obtained test results that can be explained as follows:

\section{a). First Hypothesis Testing}

$\mathrm{H} 0: B 1=0$ : there is no influence of leadership on personnel performance.

Ha: $\beta 1 \neq 0$ : there is a positive influence of leadership on personnel performance.

If $\mathrm{t}>\mathrm{t}$ table, then $\mathrm{H} 0$ is rejected and $\mathrm{Ha}$ is accepted.

\section{a. T test}

Based on the results of the calculation of SPSS (Statistical Product and Service Solution) 17 for Window, the tcount obtained was 10,011 and ttable with $\mathrm{df} n-\mathrm{k}-1=67-2-1=63$ at $\alpha(0.05)$ amounted to 1,669 . Thus $\mathrm{t}$ count $10,011>\mathrm{t}$ table 1,669 so that $\mathrm{H} 0$ is rejected and $\mathrm{Ha}$ is accepted. This shows that leadership has an influence on personnel performance.

\section{b. Determination Analysis}

Based on the analysis obtained a coefficient of determination of 0.607 . This shows that $60.7 \%$ of the diversity of personnel performance is due to the diversity of leadership, while the remaining $39.3 \%$ is caused by other variables.

c. Simple Linear Regression Equation

Based on the analysis obtained simple linear regression equation values as follows:

$-\hat{\mathrm{Y}}=\mathrm{a}+\mathrm{b} 1 \mathrm{X} 1$

$-\hat{\mathrm{Y}}=0.697+0.488 \mathrm{X} 1$

This linear regression equation shows that every increase of 1 value of leadership variable can increase the value of personnel performance by 1,185 assuming constant work discipline variables.

\section{b). Second Hypothesis Testing}

$\mathrm{H} 0: B 2=0$ : there is no influence of work discipline on personnel performance.

Ha: $\beta 2 \neq 0$ : there is a positive influence of work discipline on personnel performance.

If $\mathrm{t}>\mathrm{t}$ table, then $\mathrm{H} 0$ is rejected and $\mathrm{Ha}$ is accepted.

\section{a. $\mathbf{T}$ test}

Based on the calculation results of SPSS 17 for Window, the calculated value is 9.585 and ttable with df $n-k-1=67-2-1$ $=63$ at $\alpha(0.05)$ is 1.669 . Thus tcount9.585> t table1.669 so that $\mathrm{H} 0$ is rejected and $\mathrm{Ha}$ is accepted. This shows that work discipline has an influence on personnel performance.

\section{b. Determination Analysis}

Based on the analysis obtained a coefficient of determination of 0.586 . This shows that $58.6 \%$ of the diversity of personnel performance is due to the diversity of work discipline, while the remaining $41.4 \%$ is caused by other variables.

\section{c. Simple Linear Regression Equation}

Based on the analysis results in testing this hypothesis obtained a simple linear regression equation as follows:

$-\hat{\mathrm{Y}}=\mathrm{a}+\mathrm{b} 2 \mathrm{X} 2$

$-\hat{\mathrm{Y}}=0.796+0.467 \mathrm{X} 2$

This linear regression equation shows that every 1 increase in the value of the work discipline variable can increase personnel performance values by 1,263 with the assumption of constant leadership variables.

\section{c). Third Hypothesis Testing}

H0: $\beta 1=\beta 2=0$ : there is no joint leadership and work discipline effect on personnel performance.

Ha: one or both $\beta \neq 0$ : there is an influence of leadership and work discipline together on personnel performance.

If Fcount> Ftable, then $\mathrm{HO}$ is rejected and $\mathrm{Ha}$ is accepted.

\section{a. F test}

Based on the results of SPSS (Statistical Product and Service Solution) 17 calculations for Window, the calculated Fcount value is 92,518 and Ftable with df $n-k-1=67-2-1=63$ at $\alpha(0.05)$ is 3,143. Thus Fcount92.518> Ftable3.143, so $\mathrm{HO}$ is rejected and $\mathrm{Ha}$ is accepted. This shows that leadership and discipline of cooperation together have an influence on personnel performance.

b. Determination Analysis

Based on the analysis obtained a coefficient of determination of 0.743 . This shows that $74.3 \%$ of the diversity of personnel performance is due to the diversity of leadership and work discipline, while the remaining $25.7 \%$ is caused by other variables.

c. Multiple Linear Regression Equations

Based on the analysis in testing this hypothesis obtained by the multiple linear regression regression equation as follows:

$-\hat{\mathrm{Y}}=\mathrm{a}+\mathrm{b} 1 \mathrm{X} 1+\mathrm{b} 2 \mathrm{X} 2$

$-\hat{\mathrm{Y}}=0.405+0.312 \mathrm{X} 1+0.283 \mathrm{X} 2$

The definition of double linear equation above is:

- That every increase of 1 value of leadership variable can increase personal performance by 0.717 with an estimated variable work discipline constant. 
- That every increase of 1 value of the work discipline variable can increase the performance value of personnel by 0.688 with the estimated constant leadership variable.

\section{Discussion of Research Results}

The results of data processing are processed using the SPSS 17 for Windows program and research findings.

\section{Leadership $\left(\mathbf{X}^{1}\right)$}

Based on calculations and the average score of respondents' assessment of each dimension in the variable Leadership $\left(\mathrm{X}^{1}\right)$ can be described as follows:

\section{Task Dimensions}

The average rating of respondents towards the dimensions of the task obtained an average of 4,318. this indicates that the respondent agreed or agreed with the statement submitted. In the task dimension, the average indicator scores are lowest to highest, namely (1) a clear structure, (2) a spokesperson, and (3) overseeing.

\section{Dimensions of Responsibility}

The average rating of respondents towards the dimensions of responsibility obtained an average of 4,249. this indicates that the respondent agreed or agreed with the statement submitted. In the dimension of responsibility, the average indicator scores are lowest to highest, namely (1) Paying attention, (2) Completing infrastructure, (3) Removing obstacles, (4) Delegating authority, (5) Communication, (6) Encourage, and (7) Assess the results.

\section{Dimensions of Characteristics}

The average rating of respondents towards the characteristic dimension obtained an average of 4,370. this indicates that they agree or agree with the statement submitted. In the characteristic dimension, the average indicator scores are lowest to highest, namely (1) Unifying, (2) Broad insight, (3) Empowerment, (4) Integrity, and (5) Emotion control.

\section{Work Discipline $\left(\mathbf{X}^{2}\right)$}

Based on the calculation of the average score of respondents' assessment of each dimension in the Work Discipline variable $\left(\mathrm{X}^{2}\right)$ can be described as follows:

\section{Dimensions of Timeliness}

The average rating of respondents on the dimension of time accuracy was 4,368. this indicates that the respondent agreed or agreed with the statement submitted. In the dimension of timeliness, the average score of the lowest to highest indicator, namely (1) Behavior according to regulations, (2) Present on time, and (3) Orderly.

\section{Dimensions of Use of Office Equipment}

The average rating of respondents on the dimensions of the use of office equipment was an average of 4,308. this indicates that the respondent agreed or agreed with the statement submitted. In the dimensions of office equipment use, the average score of the lowest to highest indicator, namely (1) Do not bring office equipment to home, (2) Be careful using equipment, and (3) Do not damage office equipment.

\section{Dimensions of Responsibility}

The average rating of respondents towards the dimensions of responsibility was obtained on average by 4,293. this indicates that the respondent agreed or agreed with the statement submitted. In the dimension of responsibility, the average score of the indicator is the lowest to the highest, namely (1) Being polite, (2) The task must be completed properly, (3) Having equality, (4) Having high discipline, and (5) Have loyalty.

\section{Dimensions of Obedience}

The average respondent's evaluation of the obedience dimension was 4,293. this indicates that the respondent agreed or agreed with the statement submitted. In the dimension of obedience, the average score of the indicator is the lowest to the highest, namely (1) The implementation of the penalty, (2) Must comply with the provisions, (3) Reprimand negligent personnel, and (4) Have a commitment.

\section{Personnel Performance (Y)}

Based on calculations and the average score of respondents' assessment of each dimension in the Personnel Performance variable (Y) can be described as follows:

\section{Dimensions of internal factors of personnel}

The average rating of respondents on the dimensions of internal personnel factors obtained an average of 4,739. this indicates that the respondent agreed or agreed with the statement submitted. In the dimensions of internal personnel factors, the average indicator scores lowest to highest, namely (1) work performance, (2) skills, (3) strategy, (4) comparative studies, (5) abilities, (6) ideas.

\section{Dimensions of internal environmental factors}

The average rating of respondents on the dimensions of internal environmental factors obtained an average of 4.669. this indicates that the respondent agreed or agreed with the statement submitted. In the dimensions of internal environmental factors, the average score of indicators is lowest to highest, namely (1) Leadership actions, (2) Organizational management, (3) Work program, (4) Development of personnel, (5) Organizational goals, and (6) Large expenditure.

3. Dimensions of external environmental factors

The average rating of respondents on the dimensions of external environmental factors obtained an average of 4,293. this indicates that the respondent agreed or agreed with the statement submitted. In the external environment dimension, the average score of indicators is lowest to highest, namely (1) Method, (2) Organizational program, and (3) Receiving input.

\section{Findings and Practical Implications of Research Results}




\section{Findings and Effects of Leadership on Personnel Performance}

Based on the results of the analysis of research data that has been done, it has been proven that the Effect of Leadership and Discipline on the Performance of the Kodam Jaya / Jayakart Personnel who took samples from the executing unit namely Ajendam Jaya. amounted to 0.859 . Furthermore, it has a positive and real effect on service quality by $60.7 \%$.

\section{Findings and Effects of Discipline on Personnel Performance}

Based on the results of the analysis of research data that has been done, it has been proven that there is a finding of a positive influence on the variable work discipline with the highest value with the dominant indicator being present on time amounting to 0.918 loyalty amounting to 0.902 . Furthermore, policy implementation has a positive and significant effect on service quality by $58.6 \%$.

\section{Findings and Effects of Leadership and Discipline Together Against Personnel Performance}

Based on the results of the analysis of research data that has been done, it has been proven that there is a finding of a positive influence on the personnel performance variable of the highest value with the dominant indicator being the organization with 0.823 skills at 0.749 . Furthermore, leadership and together have a positive and tangible influence on the performance of the people by $74.3 \%$.

Whether or not the performance of personnel can be influenced by leadership and work discipline factors. The success of an organization is determined by the leadership that is developed in the organization given to subordinates to achieve goals. Without good leadership, it will be difficult to achieve organizational goals, even to adapt to changes that are happening inside and outside the organization. A harmonious relationship between personnel and leaders is a problem that needs attention when connected with job satisfaction. While work discipline is very necessary in order to be able to carry out its work programs to achieve the targets set. If personnel have high work discipline, it will help improve personnel performance.

\section{Conclusion}

\section{CLOSING}

The conclusions of this study include:

1. There is a positive and significant influence of leadership on the performance of Kodam Jaya / Jakarta personnel at $60.7 \%$. Where the dominant leadership influence is due to the diversity of leadership with its dominant indicators being clear structure, broad insight, monitoring, communication and completeness of infrastructure, while $39.3 \%$ is caused by variables not examined.

2. There is a positive and significant influence of work discipline on the performance of Kodam Jaya / Jakarta personnel by $58.6 \%$. Where the influence of discipline on the performance of the dominant Kodam Jaya personnel is organizational management, skills, organizational programs, receiving input and the amount of expenditure, while $41.4 \%$ is caused by variables not examined.

3. There is a positive and significant influence of leadership and work discipline together on the performance of Kodam Jaya / Jakarta personnel by $74.3 \%$. where the influence of leadership and discipline together dominantly affecting the performance of personnel is an indicator of leadership diversity, work discipline, while $25.7 \%$ is caused by variables not examined.

\section{Suggestion}

To improve the performance of Kodam Jaya / Jakarta personnel who took samples from the implementing unit, Ajendam Jaya as my work unit going forward, it needs to be followed up with:

1. Spread the coaching mechanism more accommodating to security conditions.

2. Formulate and coordinate personnel development in an effort to improve personnel performance according to organizational management and organizational programs in the Kodam Jaya environment as a vehicle to improve the performance of personnel development to obtain a common perception in the implementation of future tasks and to continue the reform program within the TNI in order to support the Tupoksi - TNI and Kodam Jaya in particular.

3. The officers in the Section in their respective units, direct, encourage and regulate all members in the implementation of work. Officers at morning apple held a check on the number of members to increase discipline. Provide motivation and encouragement of work enthusiasm to members, say the Aji TNI Sapta clan santi, Oath of Warriors, and 8 compulsory TNI. Organize members in work according to their respective duties. Accompanying members in carrying out tasks, provides examples of how good to carry out the task. Give rewards to members who get achievements and give punishes for violators. Providing opportunities for courses to members to increase member knowledge, provide facilities that fit the needs of the work to facilitate the main tasks.

\section{REFERENCES}

[1] Anoraga, Pandji, 2004, Manajemen Bisnis, Jakarta: Penerbit Rineka Cipta.

[2] Azhar Arsyad, M.A. 2002. Media Pembelajaran. Jakarta: Rajawali Pers.

[3] Bambang, Wahyudi, 2001, Manajemen Sumber Daya Manusia, Yogyakarta: Universitas Gajah Mada.

[4] Bangun, Wilson, 2012, Manajemen Sumber Daya Manusia, Jakarta: Erlangga.

[5] George, Terry, 2001, Office Management and Control, Seventh Edition $7^{\text {th }}$, Home Wood Illinois, Richard D. Irvin Inc.

[6] G.R. Terry. 2010. Manajemen Sumber Daya Manusia. Edisi Pertama. Cetakan Pertama. Jakarta: Penerbit Kencana.

[7] Handoko, T. Hani., 2004, Manajemen Personalia dan Sumber Daya Manusia, Yogyakarta: BPFE. 
[8] Hasibuan, Malayu S.P., 2002, Manajemen Sumber Daya Manusia dan Kunci Keberhasilan, Edisi Keempat, Jakarta: Penerbit CV. Haji Masagung.

[9] Hasibuan, Malayu. 2012. Manajemen Sumber Daya Manusia. Jakarta: PT Bumi Aksara.

[10] 2006, Organisasi dan Motivasi Dasar Peningkatan. Produktivitas, Jakarta: Bumi Aksara.

[11] I Made Wirartha, 2006, Pedoman Penulisan Usulan Penelitian Skripsi dan Tesis, Yogyakarta: Penerbit Andi.

[12] Islamy, M. Irfan, 2002, Prinsip-Prinsip Perumusan Kebijakan Negara, Jakarta: Bumi Aksara.

[13] Kartini, Kartono, 2004, Pemimpin dan Kepemimpinan, Jakarta: PT. Rajagrafindo Persada.

[14] Keputusan Kasad Nomor Kep/430/X/2013 tanggal 31 Oktober 2013.

[15] Mahmudi, 2010, Manajemen Kinerja Sektor Publik, Yogyakarta: UPP STIM YKPN.

[16] Mangkunegara, A.P., 2006, Manajemen Perusahaan (cetakan ketiga), Bandung: PT Remaja Rosdakarya Offset.

[17] Mangkuprawira \& Aida Vitayala Hubeis, 2007, Manajemen Mutu Sumber Daya Manusia, Bogor: Ghalia Indonesia.

[18] Moenir, H.A.S., 2001, Manajemen Pelayanan Umum di Indonesia, Jakarta : Bumi Aksara.

[19] Moh. As'ad, 2001, Psikologi Industri, Seri Ilmu Sumber Daya Manusia, Yogyakarta: Liberty.

[20] Nasution, S., 2006, Pengembangan Kurikulum. Bandung: Citra Aditya Bakti.

[21] Nitisemito, Alex, 2002, Manajemen Personalia, Jakarta: Ghalia Indonesia.

[22] Peraturan Pemerintahan No. 39 Tahun 2010.

[23] Rivai, Veithzal, 2011, Kepemimpinan dan Perilaku Organisasi, Jakarta: Penerbit Raja. Grafindo Persada.

[24] Sahlan Asnawi, 2003, Aplikasi Psikologi dalam Manajemen Sumber Daya Manusia Organisasi, Jakarta: Penerbit Pusgrafin.

[25] Sedarmayanti, 2007, Manajemen Sumber Daya Manusia Reformasi Birokrasi dan Manajemen Pegawai Negeri Sipil, Bandung: PT. Refika Aditama.

[26] Setiyawan, Budi dan Waridin, 2006, "Pengaruh Disiplin Kerja Karyawan dan Budaya Organisasi Terhadap Kinerja Di Divisi Radiologi RSUP Dokter Kariadi Semarang”. Jurnal. JRBI Vol 2 No 2 Hal 181-19.

[27] Siagian, Sondang P., 2003, Teori \& Praktek Kepemimpinan, Jakarta: Rineka Cipta.

[28] Simamora, 2004, Manajemen, Edisi Ketiga. Yogyakarta: STIE YPKN.

[29] Sindoro, 2006, Manajemen, Jakarta: Penerbit PT. Prenhallindo.

[30] Singodimedjo, Markum, 2002, Manajemen Sumber Daya Manusia, Surabaya: SMMAS.

[31] Soegeng Prijodarminto, 2005, Disiplin Kiat Menuju Sukses, Jakarta: Penerbit PT. Abadi.

[32] Sudarmanto, 2009, Kinerja dan Pengembangan Kompetensi SDM, Yogyakarta: Pustaka Pelajar.

[33] Sugiyono, 2012, Metode Penelitian Kuantitatif Kualitatif dan R\&D, Bandung: Alfabeta.

[34] Suradinata, Ermaya, 2005, Pemimpin dan Kepemimpinan Pemerintahan. Jakarta: PT. Gramedia Pustaka Utama.

[35] Sutarto, 2002, Dasar-dasar Organisasi, Yogyakarta: Gadjah Mada University Press.

[36] Syamsi, Ibnu, 2001, Pokok-Pokok Organisasi dan Manajemen, Jakarta: Rieneka Cipta.

[37] Taliziduhu, Ndraha, 2005, Teori Budaya Organisasi, Jakarta: Bumi Aksara.

[38] Tika, Pabundu, 2010, Budaya Organisasi dan Peningkatan Kinerja Perusahaan, Jakarta: Bumi Aksara.

[39] Thoha, Miftah, 2003, Kepemimpinan Dalam Manajemen. Jakarta: PT. Raja Grafindo Persada.

[40] _ 2010, Kepemimpinan dan Manajemen. Jakarta: Penerbit Rajawali Pers.

[41] Triguno, 2005, Kualitas Pegawai, Jakarta: Bumi Aksara.

[42] Wirawan, 2009, Evaluasi Kinerja, Jakarta: Salemba Empat. 